the learning context; maybe not as a "guide on the side", but as a (co)designer of learning situations, mediator, and colearner in the search for information, the construction of knowledge, the development of competences, and the creation of opportunities for real and meaningful communication.

While we continue to develop and explore new ways of using online media, "teaching is indeed learning," and it will probably take a little longer to establish not only what it takes to teach online but also how we learn to teach online. Some of the challenges that lie ahead of us are: 1. multimodality and new literacies, 2. open source/open content, and 3. online tutor training on a larger scale. The increasing convergence of technologies makes new and different cognitive demands on tutors and learners. Open source/open content make it all the more important to think of delivery as well as content, of pedagogy as well as affordances, and of teachers (virtual or real) as well as materials. Open content will only become relevant when what is offered is pedagogically prepared material rather than a haphazard collection of lecture notes. On the other hand, learning activities prepared for one cultural context might have to be re-thought or re-presented for the global audience of open accessibility in order to meet culturally diverse learners' styles and needs. Language professionals are ideally placed for this task of localizing. Finally, online language teacher training is already gaining prominence, funding. It is likely that investigations of online teaching and online tutor skills similarly rely on enthusiastic teachers prepared to experiment with and reflect on their online teaching practice and its challenges. While we have presented here a range of views on the tasks and challenges of online pedagogy, a systematic overview of teacher training methods and reflective practice in online language teaching, a "How do we learn to teach online" collection might be the next step that is needed to carry this endeavor forward.

1. Felix, U. (2005). E-learning pedagogy in the third millennium: the need for combining social and cognitive constructivist approaches. ReCALL,17(1), 85-100 p.

2. Hampel, R., \& Stickler, U. (2015). New skills for new classrooms: Training tutors to teach languages online. Computer Assisted Language, 18 (4), 311-326 p.

3. Thorne, S. L. (2015). Internet-mediated intercultural foreign language education: Approaches, pedagogy, and research, 31, 51-71p.

\title{
Kramarenko L.V. \\ Social service as a basis of pedagogical practice of future social teachers (on the example of Yalta)
}

Humanitarian and pedagogical academy (branch) of the Federal state autonomous educational institution of higher education "Crimean federal university named after V.I.

Vernadsky»

(Russia, Yalta)

doi: $10.18411 / \mathrm{j}-05-2020-322$

idsp: ljournal-05-2020-322

\section{Abstract}

The article analyzes legislative regulation and a scientific approach to studying the problems of centers of social services for families, children and youth. The experience of centers for the organization and conduct of undergraduate teaching practice by future social educators is considered. The features of the formation of professional competence of future specialists on the basis of the students' practical activities on the basis of the centers are investigated. Actual directions of researching the centers' positive experience in preparing future social educators in working with needy categories of the population are proposed.

Key words: teaching practice; professional competence; social service; social teacher; subject of social work. 


\section{Аннотация}

В статье проанализированы законодательное регулирование и научный подход к изучению проблематики центров социальных служб для семьи, детей и молодежи. Рассмотрен опыт центров по организации и проведению преддипломной педагогической практики, будущими социальными педагогами.

Исследованы особенности формирования профессиональной компетентности будущих специалистов на основе практической деятельности студентов на базе центров. Предложены актуальные направления исследования положительного опыта центров в подготовке будущих социальных педагогов в работе с нуждающимися категориями населения.

Ключевые слова: педагогическая практика; профессиональная компетентность; социальная служба; социальный педагог; предмет социальной работы.

At the present stage of development of our state in the context of socio-economic and legal transformations, interest in the modernization of the socio-pedagogical sphere is rapidly growing. In the context of the reform of education in accordance with the updated education paradigm, implemented in the interests of man, family, society and the state, the problem of modernization of the vocational training system for future social educators is becoming extremely urgent. The formation of readiness of students - future social educators for professional activities, during a period of systemic changes, should be filled with social content.

One of the priority points in this case is the search for effective ways to ensure the unity of theory and practice in a multi-level educational process, the development of a holistic system of continuous educational and practical training of students. In the vocational training system, the most important place is occupied by pedagogical practice, aimed at the implementation of pedagogical knowledge, abilities of students and the improvement of pedagogical skills of future social educators.

In our opinion, the most productive professional training of social educators is possible on the basis of institutions of the sphere of social support of the population that effectively solve the problems of families, children and youth, in particular, centers of social services for families, children and youth (further - centers). In connection with the adoption of the Republic of Crimea as part of the Russian Federation and the formation of new constituent entities, Crimea is in a new legal field, and the network of centers is becoming one of the most important subjects of social and educational work. At the same time, the experience of social service centers as a practice base for future social educators has not been sufficiently studied and requires further reflection.

O.V. Bezpalko was involved in certain questions of studying the pedagogical activity of centers [1, p. 268], T. V. Semigina [2, p. 188], M. I. Kirikov [3, p. 5], I. D. Zvereva [6, p. 328], A. I. Kapskaya [7, p. 92], A. M. Grinenko [8, p. 210], T. N. Fateeva [9, p. 8] and other researchers.

The purpose of the article is to study the experience of the activities of social services centers in the implementation of the pedagogical model for the development of professional competence of future social educators in the process of pedagogical practice. The practice of students of higher pedagogical educational institutions is an integral component of educational and professional training of specialists, the main task of which is to consolidate the theoretical knowledge obtained in the learning process, the formation of professional skills among students, mastery of modern methods and forms of work. During practice, the foundations of the experience of professional activity are laid, the prerequisites for the personal development of a future specialist are formed. Professional practice is the main component of the student's practical training process. It is based on the continuity and sequence of its implementation, the integration of theory and practice. The purpose of the practice is to master students with modern methods, forms of organization and tools in the 
field of their future profession, to form, on the basis of knowledge, professional skills and abilities for them to make independent decisions during a specific work, acquired in a higher educational institution, to educate the need to systematically update their knowledge and apply it creatively in practice.

«Modern higher professional education puts forward the task of forming a wide range of professional competencies of graduates, and the country's universities are interested in preparing competitive specialists in demand on the modern labor market» [1]. In recent years, the problem of practical orientation of education in higher educational institutions has become particularly relevant. New professional standards determine the competency-based approach of the future teacher, which is formed in the context of continuous educational practice.

One of the bases of practice for the future social educator in Crimea is the centers. These institutions for the Russian state are a positive legacy of the system of bodies of social work created and developed in Ukraine. Since 1992, a new institute of social education has been created in Ukraine - the center of social services for youth, which was predetermined by a number of factors: Ukraine's independence, socio-economic restructuring in the country, and the rapid spread of negative phenomena among young people. The famous researcher A. M. Grinenko argued that «centers of social services for youth are special institutions authorized by the state to participate in the implementation of state youth policy by conducting social work with children and youth» [8, p. 210]. In the textbook "Introduction to Social Work", as well as the textbook "Social Pedagogy" edited by Professor A. I. Kapskaya, «the centers of social services for youth are understood as specialized institutions entrusted by the state with the task of practical implementation of support for the social formation and development of youth» [2, p. 188; 9 p. 92].

All centers of social services for youth are united by a common goal, they are a single mechanism of the state in the implementation of social policy for youth, thus forming a system - a set of elements united by common signs and purpose [4; 5].

The system of centers of social services is characterized by hierarchical structure and orderliness of its structural units, which ensures its stability, flexibility and dynamism. In the Russian Federation, there are centers for social assistance to families and children, which are similar in scope to the centers under consideration, but work in a stationary form, do not have hierarchical structure, and are not an obligatory link in the implementation of state social policy.

T.N. Fateeva believes that «the center for social assistance to families and children is a multifunctional institution focused on creating the conditions for implementing comprehensive social assistance programs for various categories of families with children in the form of socio-pedagogical, psychological, medical, legal, and economic services. Such a center is an open socio-pedagogical system that helps prevent the neglect of minors, integrates various types of socially significant leisure activities and communication between children and adolescents, and complements the educational potentials of traditional institutions of socialization of the younger generation» [9, p. 8]. M.I. Kirikova considered «the centers of social assistance to families and children in the broad sense - as state institutions related to the social service system, which are designed to facilitate the implementation of family policy in the Russian Federation» [3, p. 5].

In the new legal realities, it is imperative to take into account the positive experience of the network of social services centers as a base for undergraduate practice for future social educators. The experience accumulated by the centers services for the family, children and youth of the Republic of Crimea in this direction of work, in cooperation with other entities, is new in the Russian Federation and necessary on the way to improving the social guidelines of our country. For example, in accordance with the agreement between the State Budgetary Institution of the Republic of Crimea "Yalta Center for Social Services for Family, Children and Youth" and the Humanitarian and pedagogical academy (branch) of the Federal state autonomous educational institution of higher education «Crimean federal university named 
after V.I. Vernadsky» in Yalta (Russia, Yalta), students of the specified educational institution, mastering the bachelor's program in the direction of preparation 44.03.02“ Psychological and pedagogical education ", undergo pre-diploma practice at the center.

Undergraduate practice is the final in the system of applied training of bachelors and includes research on the topic of final qualification work (bachelor's work), the application and deepening of theoretical knowledge gained during the training period, as well as the acquisition of practical skills to solve professional problems corresponding to the competency model graduate. Undergraduate practice is carried out in accordance with the schedule of the educational process with a separation from training, the total complexity: 6 credits - 216 hours. Semester of undergraduate practice - 8th.

In the process of this practice, students should form the following general professional and professional competencies: the ability to take into account general, specific patterns and individual characteristics of mental and psychophysiological development, especially the regulation of human behavior and activity at various age levels; the ability to effectively interact with teachers of educational organizations and other specialists on child development issues; the ability to apply technologies of socio-pedagogical work and the design of sociopedagogical processes, taking into account the specifics of the region, community, subjects of interaction.

Students study the main activities of the institution, staffing, structure, regulatory framework of state support for families and people in difficult situations and socially dangerous situations. They analyze the composition, content of services provided in the framework of social work with families, children and youth, the principles of the provision of services and requirements for working with recipients of services. Consider the essence of the forms and methods of social work with clients of the institution.

They participate in the organization of interagency cooperation between the authorities of the prevention system to prevent neglect and juvenile delinquency, as well as in group events, city actions for families, children and youth. They study "work with the case" as a key technology for working with families who find themselves in difficult life situations and socially dangerous situations.

This type of practice is based mainly on the diagnostic component, students in the process of practice master the psychological and pedagogical methods and technologies of diagnostic activity, which is a fundamental factor in the professional preparation of students for social and educational activities. The final stage of the practice is built up from selfdiagnosis of the level of professional competence through reflection and analysis of the student's own activities, drawing up a practice report with a diary application that describes daily activities in accordance with the tasks completed, to participating in the final conference and passing the test in the form of a colloquium, the goal which is a test of knowledge and skills acquired by students in the process of practice.

In the process of organizing the practice, special attention deserves the holding of a final scientific and practical conference, at which students 'reports on their practical activities are presented with presentation materials, and the main aspects of the procedural side of the practice, such as the structure, content and results of students' independent activities, are discussed and worked out. The practical activity of students helps to consolidate the skills of educational, scientific and professional activities, as well as personal realization and selfactualization. During the practice, students have the opportunity to verify the correctness or fallacy of professional self-determination. In the process of practice, practical and theoretical knowledge is integrated and differentiated, real socio-pedagogical problems are recognized and the most effective ways to solve them are revealed. Students during practice learn to see the socio-pedagogical meaning of their activities, which makes it possible to realize the social value of their work and imbued with self-esteem. The formation of a student as a social teacher occurs not only in the process of assimilation of the content and modern methods and 
technologies of vocational education, but also in the development of his individual work style in the course of practice.

Based on the foregoing, it can be concluded that the development of a network of social services centers for families, children and youth of the Republic of Crimea is an important step in the social policy of our state, and the practical training of students on the basis of the centers is a leading link in professional social and pedagogical education of future social educators. In the process of undergraduate practice on the basis of social services centers, students synthesize minimal experience in a given area with established personal qualities, which forms the professional competence of future specialists.

The novelty of the study consists in the practical formation of pedagogical skills in a new subject of social work for the Russian legal field. The study of students' practical activities on the basis of social services centers will allow to differentiate the sphere of activity between the subjects of social work, especially in terms of solving sociopsychological and socio-pedagogical problems. The current direction of the study is to study the positive experience of training future social educators on the basis of a network of social services centers, which will improve the pedagogical experience of working with needy categories of the population.

$$
* * *
$$

1. Безпалько О. В. Організація соціально-педагогічної роботи з дітьми та молоддю у територіальній громаді: теоретико-методичні основи: монографія. К.: Наук. світ, 2006. 408 с.

2. Введення у соціальну роботу: навчальний посібник / авт. кол. Бойко А. М., Грига І. М., Кабаченко Н. В., Кравченко Р. І., Полтавець Д. В., Семигіна Т. В. та ін. - К.: Фенікс, 2001. 288 с.

3. Кирикова М. И. Повышение воспитательного потенциала неполной семьи в условиях центра социальной помощи семье и детям: автореф. дисс. к. пед. н. М., 2009. 21 с.

4. Об основах социального обслуживания граждан в Российской Федерации [Электронный ресурс]:

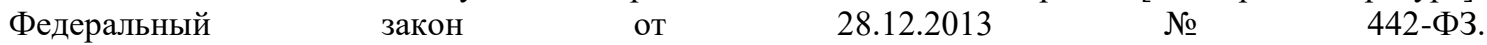
URL:http://www.consultant.ru/document/cons_doc_LAW_156558/f71c6aa6eddc4156c5c798ae0e9f5d72 ff2392c0/ (дата обращения: 01.11.2019).

5. Про соціальну роботу з сім'ями, дітьми та молоддю [Электронный ресурс]: закон України від 21.06.2001 № 2558-III. URL: http://zakon2.rada.gov.ua/laws/show/25584?test=4/UMfPEGznhh/m8.ZisT24nBHI4xYs80msh8Ie6 (дата обращения: 01.11.2019).

6. Соціальна педагогіка: мала енциклопедія / за заг. ред. проф. І. Д. Звєрєвої. К.: Центр учбової літератури, 2008. 336 с.

7. Соціальна педагогіка: підручник / за заг. ред. А. Й. Капської. - Київ: Центр навчальної літератури, 2003. $256 \mathrm{c}$.

8. Соціальна політика: навч.-метод. посіб. для самост. вивч. дисципліни / за заг. ред. А. М. Гриненко. К.: КНЕУ, 2003. 309 c.

9. Фатеева Т. Н. Социально-педагогическая профилактика безнадзорности подростков в условиях центра социальной помощи семье и детям: автореф. дисс. к. пед. н. М., 2008. 23 с.

10. Шилова М. И., Белых И. Л. Формирование конкурентоспособности выпускника вуза // Вестн. Томского гос. пед. ун-та (Tomsk State Pedagogical University Bulletin). 2010. Вып. 4. С. $39-45$. 